LOCAL WISDOM, 11 (2): 90-106, 2019
Local Wisdom Scientific Online Journal
ISSN: 2086-3764 $\quad \begin{array}{r}\text { WISDOM } \\ \mathrm{w}\end{array}$

\title{
Typology of Bena Traditional Architecture, Flores
}

\author{
Zulkifli H.Achmad ${ }^{\text {* }}$ \\ 1. Magister Architecture, University of Brawijaya, Malang, Indonesia \\ Corresponding Author: : zul_archflores@yahoo.com
}

\begin{abstract}
Keywords: traditional architecture, kampung bena, typology forms

Traditional architecture Bena has its own peculiarities and characteristics both in architectural form and in philosophy were conceived shape of the building and have a close relationship with the social and cultural setting. Characteristics of a building can sort by typology. Elements of traditional architecture can be a characteristic of the region. Making an area and remind the person or people in a given environment. Traditional building custom homes Bena community is one manifestation of which is concrete. The research method is qualitative descriptive. The purpose of this study was to determine the typology of traditional settlements Bena an attempt inventory and documentation of traditional architecture Bena. From the result of this writing, there are two forms of the observation that in macro and micro. Macro is the place to stay for people Bena while micro elements supporting the settlements and other facilities. Results of this paper show that there are two types of observations in traditional architecture itself, namely: In the macro, Sa, Pu Saka o, u, Sa, o Saka Lobo, Sa, while the micro-o Kaka is Ture Ago-Ngadha, Peo, Ngadhu, Bagha, Ture, Kapela and Gua maria.
\end{abstract}

Kata Kunci:

Arsitektur

Tradisional, Kampung Bena , Tipologi Bentuk

\section{Abstrak}

Arsitektur Tradisional Bena mempunyai kekhasan dan ciri tersendiri baik dalam bentuk arsitekturalnya maupun filosofi yang dikandung bentuk bangunannya dan mempunyai hubungan yang erat dengan setting sosial budaya masyarakat. Karakteristik suatu bangunan dapat ditinjau berdasarkan tipologi. Elemen-elemen arsitektur tradisional dapat menjadi karakteristik dari suatu daerah tersebut. Menjadikan suatu daerah dan mengingatkan orang atau masyarakat terhadap suatu lingkungan tertentu. Bangunan tradisional rumah adat masyarakat Bena, merupakan salah satu wujud yang bersifat konkret. Metode penelitian dilakukan secara kualitatif deskriptif. Tujuan penelitian ini adalah untuk mengetahui tipologi permukiman tradisional Bena sebagai upaya inventarisasi dan dokumentasi arsitektur tradisional Bena. Dari hasil tulisan ini terdapat dua bentuk dalam pengamatan yaitu secara makro dan mikro. Makro lebih kepada tempat tinggal bagi masyarakat bena sedangkan secara mikro elemen-elemen penunjang dalam perkampungan dan fasilitas lainnya. Hasil tulisan ini menunjukkan bahwa ada dua jenis pengamatan dalam arsitektur tradisional itu sendiri, yaitu: Secara makro, Sa,o Saka Pu,u, Sa,o Saka Lobo, Sa,o Kaka sedangkan secara mikro yaitu Ture Ago-Ngadha, Peo, Ngadhu, Bagha, Ture, Kapela dan Gua maria. 


\section{Introduction}

Traditional architecture is a very large asset and needs to preserve because it has a high cultural value so that it can give a broad insight into the planners in carrying out the design. Moreover, traditional architecture has an important meaning as an architecture that reflects the ideas and behaviour of a society ${ }^{1}$. The birth of traditional architecture from these buildings usually motivated by religious norms, traditions, civilizations and the geography of the local area; which eventually led to part of the culture of the nation

Traditional architecture is part of the policy and wisdom of the development of people's living space. Its existence is closely related to the daily lives of traditional people who still adhere to the collective life order. Traditional architecture in Indonesia has certain characteristics and uniqueness that can make a big capital in tourism development.

Kampung Bena area is one of the traditional villages in the Inerie mountain valley in Ngada Regency, Flores. Bena traditional village has nine tribes or clans (woe) with a population of 320 people and 65 families. The nine clans are bena, ago, ngadha, kopa, dizi kae (Dizi A), Dizi Azi (Dizi B), Deru kae (Deru A), Detu Azi (Deru B) and Wato. The uniqueness of Kampung Bena compared to other vernacular communities is a family system adopted, that is based on the maternal lineage (matrilinear). The kinship system reflected in the village space and its architectural form.

\section{Literature of Review}

\section{Typology Architecture}

Typology is the study of types. The type comes from the word Typos (Greek), which means impressions, images, or figures of things. In general, types are often using to explain the overall shape, structure, or character of a particular shape or object. 2 When viewed from building objects, typology is dividing into three main things, namely the building site, the form of the building, and the organization of the parts of the building. Typology is a study that seeks to trace the origin or origin of the formation of architectural objects. There are three stages that must be taken, namely: 3

- First, determine the basic forms (formal structure) that exist in each architectural object.

- Second, determine the basic properties that are owned by each object, based on the basic form that is on it.

- Third, study the process of developing these basic forms up to their current manifestations.

Besides grouping based on basic forms, basic traits, and the development of architectural forms, de Quincy introduced the concept of physiognomy, which is a way of interpreting architectural objects through attempts to identify them with a particular physical object, which will produce a certain image. ${ }^{4}$ In this context, typology also is seen as an activity grouping based on style, because each object has its own type in accordance with the functions and habits of the community in using the object.

According to Rafael Moneo, typology analysis divided into 3 phases 4 :

a. Analyze typology by digging from history to find out the initial idea of a composition, or in other words to know the origin or occurrence of an architectural object.

b. Analyze typology by to know the objects function.

c. Analyze typology by to find the building simple form through finding basic form and basic nature. 
Amiuza (2006) 5 in his study said that typology is a concept of describing groups of objects based on similarities, basic characteristics that try to sort or classify forms of diversity and similarity of types. Typology is a study of types. A type is a group of objects characterized by the same formal structure, so typology is to be the study of grouping objects as models through structural similarities. According to Sulistiyowati (1991: 12) 6 , the introduction of typology will lead to efforts to "classify" group or classify based on certain aspects or rules. These aspects include: 1.) Functions (including use of space, structural, symbolic, etc.), 2.) Geometrics (including forms, principles of order, etc.), and 3.) Style(covering period, location or geography, politics or power, ethnicity and culture, etc.).

Based on all the exposure in advance, it can be concluded that typology is a concept or act of thinking within the framework of classification and grouping of architectural objects. This classification and grouping based on the similarity of basic forms, basic traits, styles, symbolism in the existing social context, and the origin and development process of architectural forms.

\section{Traditional Architecture}

The word tradition originates from the Latin traditionem, from tradition which means "handover, giving, relay", and used in various ways in the form of beliefs or habits that are taught or transmitted from one generation to the next, usually delivered in a manner and generation. 7

In the Indonesian general dictionary, Poerwadarminta (1984), the word tradition means, "everything like customs, beliefs, habits and so on that descended from ancestors. In connection with architecture, an important problem is traditions architectural and architectural traditions. Tradition architecture is an architecture that built and inhabited in accordance with traditional rules. Almost the same as what is called traditional architecture. while the architectural tradition refers to socio-cultural activities or the community calls it an activity in forming or fostering its architecture; or how society expresses itself through architecture. 8

If the understanding of architecture is associated with the understanding of tradition, then traditional architecture is the design and development carried out in the same way since several generations without meaningful changes, in order to meet the space needs to carry out certain activities.

\section{Discussion}

\section{Regional Overview}

Kampung Bena has an area of \pm 3 hectares, with a geographic shape resembling a sailboat stranded in the Jere Bu'u valley. The boundaries of the Kampong Bena are traditionally referred to as ulu Mangulewa-eko Bowoza for the boundary length is $\pm 375 \mathrm{M}$, and Bata rengo ngaba lalazala I (road environment and gorge - road) for the boundary width $\pm 80 \mathrm{M}$.

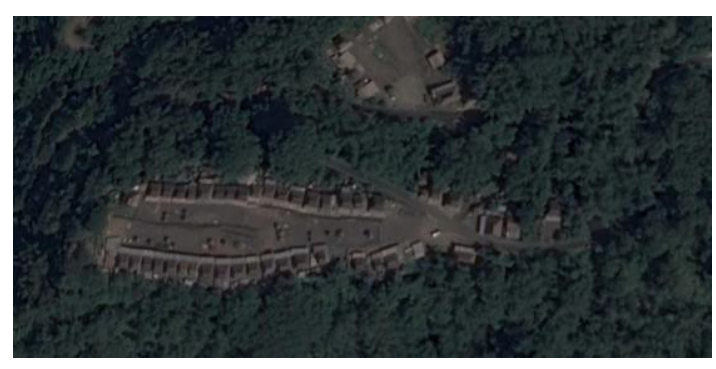

Figure 1. Bena Village Settlement Pattern (Source: Google Earth)

Kampung Bena established on (former) land of bamboo and hardwood plantations, topographic land, volcanic rock structures, and sandy soil surfaces. The central courtyard of the 
village called kisa loka, which is a large unit of nine terraces in the Kampung Bena. At the Kiso Loka custom buildings were established, such as Bhaga, Ngadhu, Peo, Tomb, Ture Woe, and Ture which restricted the zone of traditional houses to the Kisa Loka zone. There are 41 traditional houses (sao) in Kampung Bena.

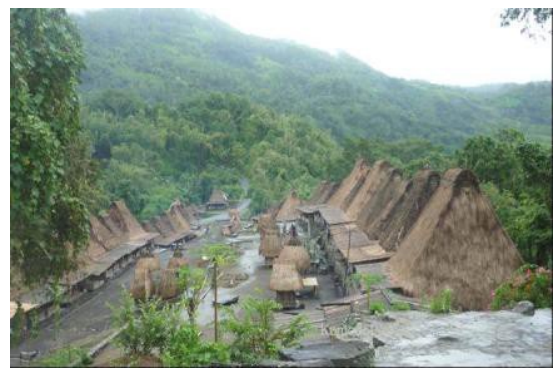

Figure 2. Kampong Bena

\section{Source: https://dians999.wordpress.com}

The environment of the Kampung Bena and the surrounding environment is becoming a world order for the indigenous people of Kampung Bena and Ngada culture in general. They have the myth that the people of Bena (and Ngada in general) are biological children of Mount Inerie (Ana Wolo ine rie). The existence of a village that is close to the great mother's arms felt to be safer and more psychologically comfortable. "The highest form" considered closer to the daily lives of the people of Kampung Bena than to live in rural villages in the lowlands. If it is associated with possible enemy attacks from the coast, then the village in a high place is more profitable than the enemy position from a lower place.

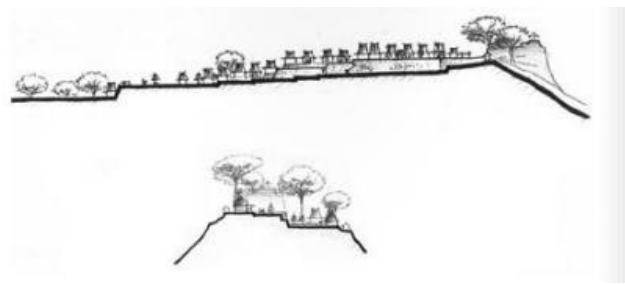

Figure 3. Pieces of Kampung Bena Settlement

Social Stratification

Source: Flores Architecture

Social stratification in Kampung Bena, are:

Gae

(is a noble group, from the tribe of Hago, Ngadha, AWAto, Deru Dizi)

Gae Kisa

(is a group of ordinary people namely from the tribe of Bena, Kopa)

$\mathrm{Sa}, \mathrm{o}$ Neo Mori

(is a slave or wasted person)

From ancient times until now there are still social layers, but there are no differences in rights and obligations. Sa,o Neomori as no longer around 70 to 80 years ago. The Bena community adheres to a matrilineal marriage so that marriage enters into the female family. Applicable inheritance law, namely women who get an inheritance, men who leave to get married do not receive the inheritance, only get fees to pay for belies (dowry). 


\section{Language}

The language in Kampung Bena is the same as Bajawa. Because Kampung Bena is a remote kampong, people rarely go out so they rarely use Indonesian. Indonesian is taught through schools and they can speak fluently even with a thick Bajawa accent.

\section{Religious}

In ancient times, the Bena people embraced the belief of infringing ancestors. Catholicism entered in 1930, and then in 1950, a chapel was built in Kampung Bena. Catholic Development Chart in Bena village.

\begin{tabular}{|c|c|}
\hline Before & Ancestral beliefs \\
\hline 1930s & Catholic enter to Bena \\
\hline 1950s & Built kapela by Mr. Rofinus Ria (ward chairman I) \\
\hline 1970s & Built Goa Maria at the top of the village \\
\hline $1980 \mathrm{~s}$ & $\begin{array}{l}\text { Restoration of } 1 \text { kapela during Mr Bernadus's tenure with } \\
\text { his master Emanuel }\end{array}$ \\
\hline $1994 \mathrm{~s}$ & $\begin{array}{l}\text { The second restoration of the Kapela during } \mathrm{Mr} \\
\text { Dominikus's tenure }\end{array}$ \\
\hline
\end{tabular}

\section{Environmental / Regional Development}

The development of the Kampung Bena environment with tourism destinations has made Kampung Bena open to accept tourism. Since 1990, the Ngada culture has entered the heritage list and has become a concern of the world community. Cultural products which, such as woven fabric, graphic arts, music art, dance, including the Bena vernacular architecture, need to be preserved artefacts and developed their cultural arts knowledge for scientific progress and prosperity for present and future generations. Therefore, the guideline for developing the Kampung Bena environment, as a tourist destination must clearly understand and support by traditional village communities in Bena village.

\section{Achievement and Circulation}

Patterns of achievement and circulation of indigenous people, visitors of tourism and goods/materials from outside to Kampung Bena, or vice versa, during both daily activities, tourist visits, and when ritual activities are linear in the pattern. tracing the ture or the pattern of freely crossing the kisa loka of the temple by caring for the tomb/stone in the middle of the village yard. The Kampung Bena has the main achievement gate, namely Bata Nua Bena and side achievements on the west and east sides of Kampung Bena, is Bata Rengo.

The achievement through the main gate was the achievement of Kampung Bena's entrance/exit through the giant scale stone buildings in the middle of the regent's ture. If through the stone steps, visitors can watch the giant 'dhake 'tapak which is believed to carry large stones in the Kampung Bena. Stone steps connect loka seu with loka wato, while the bata rengo to the east passes through the front yard of the house (wewa sao) klan dizi Kae and backyard (logo sao) klan wato on the west. 


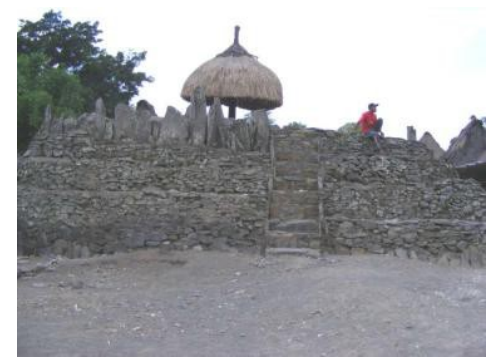

Figure 4. Structure of Kampung Bena Room

\section{Source: Flores Architecture}

\section{Components of the Outdoor Room}

Component outer space in the Kampung Bena called Loka. It is an area owned by the klan to establish traditional houses and traditional buildings. The loca boundary is determined by the deliberations of the village founders. At present, the location is an open space in front of $S a, o$ (house). Locations in each klan stood several traditional buildings such as Bhaga, Ngadhu, Peo, and ancestral stone graves. Loka in Bena village consists of 9 locations which include:

a. Loka Seu, which serves the reception room for tourist visits.

b. Loka Dizi, serves as a space for social interaction and the implementation of Woe Dizi traditional rituals.

c. Laka watu function of the space for social interaction and the implementation of Woe Wato's traditional rituals.

d. Loka Deru which is divided into two, namely

- Loka Dheru Solomae

- Loka Dheru lalulewa

Both of these Loka functions as a space for social interaction and traditional rituals of Woe Deru

e. Loka Dizi Azi, serves as a space for social interaction and the implementation of traditional rituals woe Dizi Azi.

f. Loka Kopa, function as social interaction space and the implementation of woe Kopa ritual.

g. Loka Bena, the function as social interaction space and the implementation of Woe Bena's ritual

h. Loka Ago-Ngadha, the function as social interaction space and the implementation woe Ago-Ngadha's ritual.

Wewa $S a, o$ is a field in front of $s a, o$ or land surface under the teda wewa. Piro $s a, 0$, , is a side space between two $s a$, o while the $s a \log o, o$ is the back room of a sao, behind one (middle room).

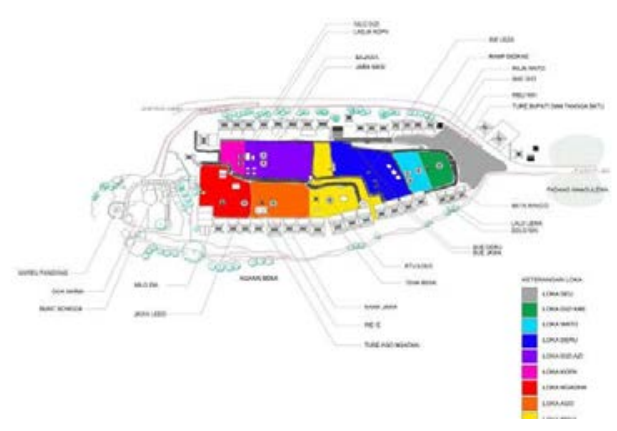


Figure 5. Structure of Kampung Bena Room

Source: Flores Architecture

\section{Traditional House}

Traditional houses (sao) and traditional buildings (bhaga, ngadhu, ture, woe, peo) have special functions and roles in creating internal and external togetherness of family members, klan and indigenous people in Kampung Bena. The function of the traditional house is dividing into three, namely:

1. Houses for families that have kinship relations.

2. A place for all daily activities and ritual activities.

3. Woven production houses, tourism objects and research visits.

The house consists of two parts, namely, a residence called one and a porch or porch building called teda. If the presence of the porch is near one, it is called teda one. If the existence of the teda is near the village, then it is called teda wewa, or teda moa.

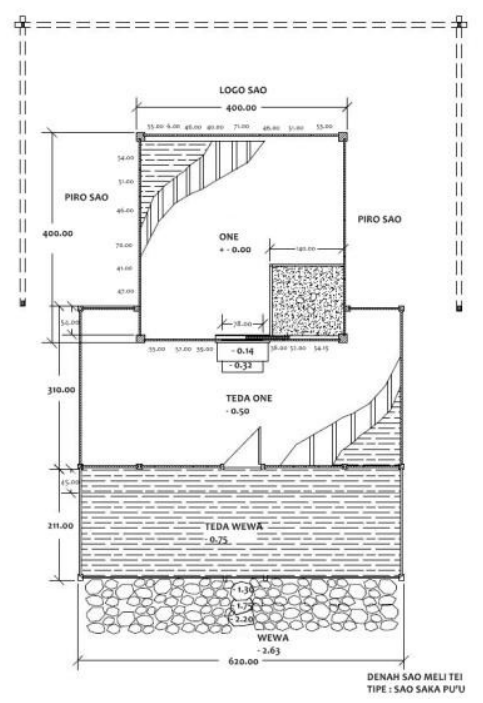

Figure 6. Traditional House Plan

Source: Flores Architecture

The house (one) is in the form of a multi-purpose room unit, which can be used to sleep, cook, eat and drink, give birth to babies, gather with family and negotiate mosalaki in solving family, klan and customary problems. The walls of the room are made with seven pieces of fai wood planks arranged in a row, and on the front side of the wall of the house, there is a sorong (pere pene) door right in the middle of one.

When one room used for traditional ritual events, there is a zone arrangement. The area in the right corner the door of the inner residence was made a fireplace, also called the traditional kitchen (tolo lapu) directly on the bamboo woven floor (naja). The place of the fireplace in the form of elevation of the floor with a size of approximately one and a half square meters, limited by wooden boards (lapu ube), filled with land and three stones (watu lika). On top of it is a storage rack for firewood (kae) with construction hanging in the roof construction. In the past, the firewood storage rack supported by a wooden pole (duke kae) at the corner, so that Kae grew stronger to be occupied by other kitchen utensils.

\section{Typology of Kampong Bena Settlements}

The typology of architectural forms in Kampung Bena settlements is based on two observations, namely macro and micro. Macro is a place of residence for the people of Bena, while in micro terms it is a supporting element in the Kampung Bena and other facilities. 
The typology of Kampung Bena 's architectural form in a macro, namely: Sa, o Saka Pu, u, Sa, o Saka Lobo and Sao Kaka.

1. Sa, o Saka $p u, u$ is a traditional building that has a crown called Anaie on the roof ridge, a miniature bhaga, a symbol of the women ancestors. Sa, o Saka Pu, u has something to do with Bhaga, which is the building of a kitchen that is always open its doors, a miniature one building. The dimensions of one in $s a$, saka $P u, u$ are the biggest compared to one on the other types of traditional houses.
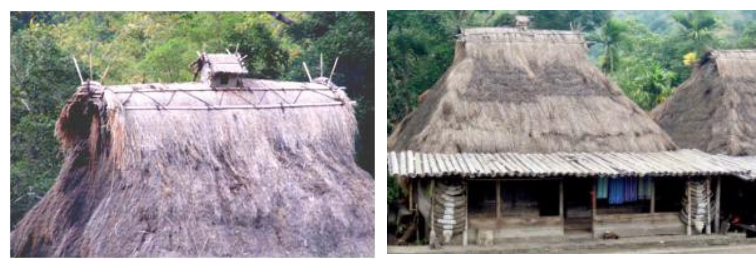

Figure 7. Sa,o Saka Pu,u

Source: Flores Architecture

2. Sa, o Saka Lobo, is a traditional house building that has a crown of roofs on Ata, a male doll from the Kampung Bena. Sa, o Saka Lobo has something to do with ngadhu, which is the building of the pilla of the victim's animal strap, the shape resembles the viewing post/gazebo, symbolizing the power of men in Kampung Bena. One dimension in Sa, o Saka Lobo is smaller than one in the Saka $P u^{\prime} u$ traditional house type.
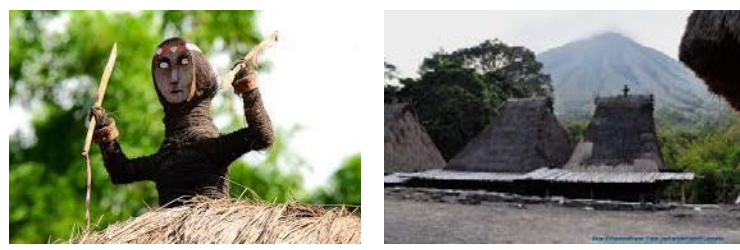

Gambar 8. Sa,o Saka Lobo

Source: Flores Architecture

3. $S a, o K a k a$, is a traditional house building that does not have a crown on the roof ridge. $S a$, o kaka has two types, one symbolizing a boy (ana saki) called sa, o kaka Lobo, and which symbolizes a girl (ana fai) called $S a$, o Kaka Pu, u. The dimensions of One Sa, o Kaka Pu, u are bigger than one in Sa, o Kaka Lobo. There are several Sa, o Kaka that has not been built in the Bena anymore, and have been moved to other villages, such as Gurusina, Tololela village or a new village.

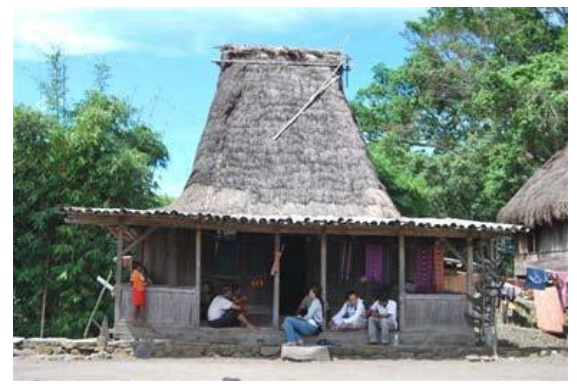

Figure 9. Sa,o Kaka 
Source: Flores Architecture

While the typology of forms of traditional settlements and other infrastructure buildings in Bena are Ture Ago-Ngadha, Peo Ngadhu, Bagha, Ture, Kapela and Gua Maria.

1. Ture Ago-Ngadhu is a menhir/megalith stone arrangement as a symbol of the tomb of the ancestors. Ture nabe meze is an upright stone that symbolizes a female ancestor, and wake watu lewa is a taller upright stone as a symbol of a male ancestor. Ture Ago-Ngadha is a joint venture between the Ago klan and the Ngadha klan, located in Ago-Ngadha district.
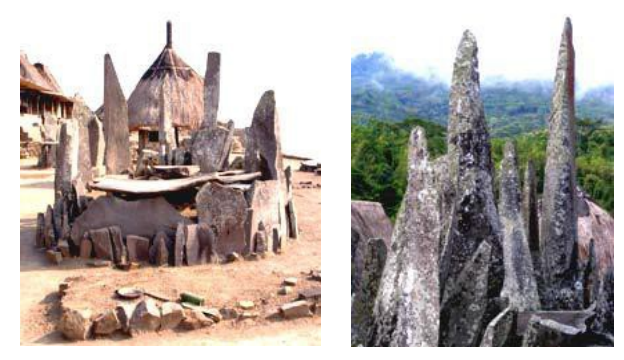

Figure 10. Ture Ago-Ngadha and Tere Nabe Meze

\section{Source: Flores Architecture}

2. Peo is an upright $\pm 40 \mathrm{~cm}$ (ture) stone that is plugged in by each tribe at its respective location around the ngadhu pole. It serves as a place to bind sacrificial animal buffalo during traditional ritual ceremonies.

3. Ngadhu, is a pillar hook of sacrificial animal buffalo rope and symbolizes the strength of men in the Kampong Bena. During the traditional ritual of buffaloes guided around Ngadhu, the snout hook tied to the ngadhu, while the legs tied to the peo. The shape resembles an umbrella pillar with two weapons (or gae and gala gae) on the roof of the $n g a d h u$. Ngadhu symbolizes the role of male guardians of the bhaga, the house of the ancestral spirits of the ancestors.

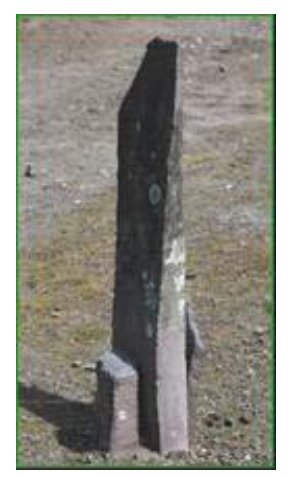

Peo

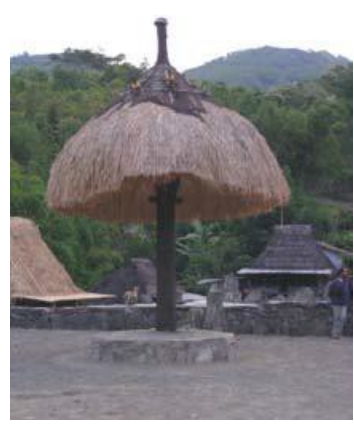

Ngadhu

Figure 11. Peo and Ngadhu 


\section{Source: Flores Architecture}

4. Bagha is one building without any difference in front of it, which always opens its doors and becomes the home of the spirits of the ancestors. The shape is like a house that has the meaning of a woman who protects, unites her husband and children. During traditional ceremonies, the community made offerings in the form of food (rice and meat) inside Bagha.

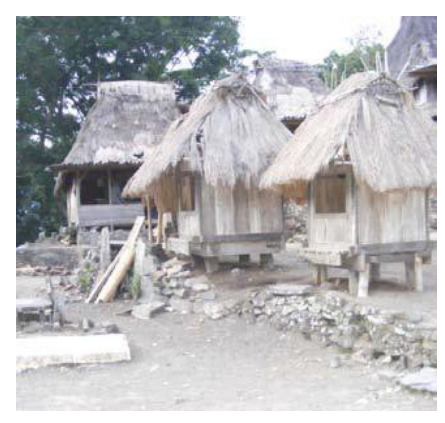

Figure 12. Bagha

Source: Flores Architecture

5. Ture is the arrangement of stones that surround the location and become a barrier between places. Ture in the Kampung Bena is very specific because it is also plaster of the landslide possibility, so it is made a simple civil construction, namely composing flat stones that have the ability to hold the ground but still provide room for groundwater to seep through the rock.
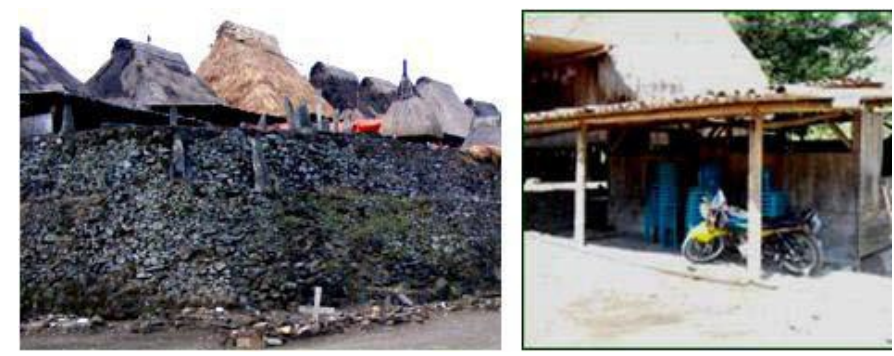

Figure 13. Ture

Source: Flores Architecture

6. Kapela is a building used as a place of worship for Catholics in the Kampung Bena, where all Bena people are Catholic. The head is the boundary used by people to refer to the upper (zele) area of Bena village and the lower (leu) area of Bena.

7. Goa Maria, is the place of the statue of Mother Mary made on Bowoza hill by Catholic youth under the care of pator Lukas (1970-qn) as a means for Bena residents who wish to devote. In addition to the worship also a viewing post or gazebo. 


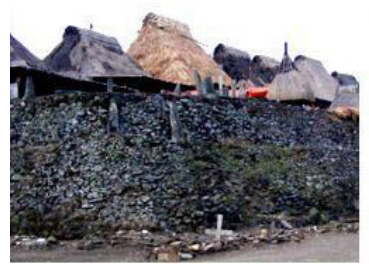

Kapela
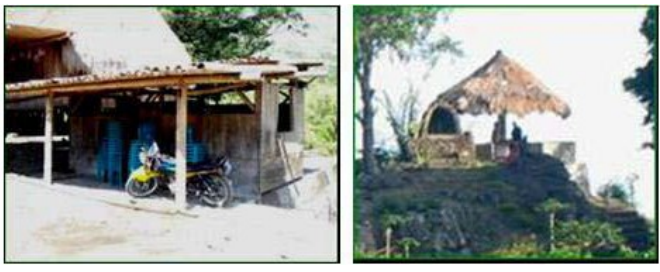

Figure 14. Kapela and Gua Maria

Source: Flores Architecture

8. Police Station is located opposite the entrance to the Kampung Bena, the shape is made to resemble the traditional house of Kampung Bena.

9. Restroom and reservoir built by the provincial government in Kampung Bena. However, its function is not as it should be due to lack of care. The reservoir is assistance from the tourism agency not functioning properly.

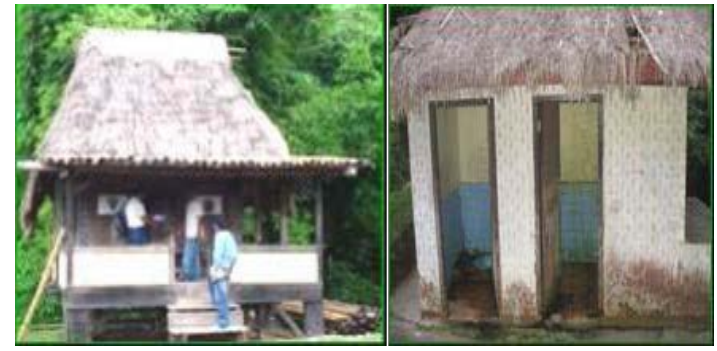

Figure 15. Police Station and Rest Room

Source: Flores Architecture

10. Home Stay made to resemble the traditional house of the Kampung Bena that is located in the division village, from the Kampung Bena that is $\pm 300 \mathrm{~m}$ away, with bedroom facilities equipped with toilets in each toilet.

11.

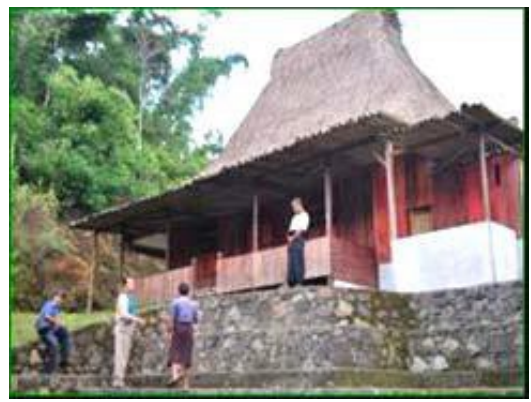

Figure 16. Home Stay

Source: Flores Architecture

12. Residents Toilets used by residents of Kampung Bena. The number of toilets in Bena village is 30 units. Some are made separate between the shower and the toilet. 
13. The pig cage is located behind the house with a direct discharge to the canyon cliffs that surround Kampung Bena, giving rise to an unpleasant odour.

14. Drainage is only in the west of the settlement bordering external roads, made of river stone and concrete with a depth of about $50 \mathrm{~cm}$.

15. Springs comes from a spring located above the hill. They made the drainage system from the Waesio spring to settlements using galvanized pipes $2.5 \mathrm{~cm}$ in diameter with participatory and self-help.

\section{Conclusion}

In general, the typology of the traditional village architectural form of Kampung Bena is divided into two parts, namely in the macro and micro or traditional houses and traditional buildings. Micro/traditional houses are divided into three parts, namely Sa,o Saka Pu,u, Sa,o Saka Lobo and Sa,o Kaka while micro/custom buildings consist of Ture Ago-Ngdha, Peo, Ngadhu, Bagha, Ture , Kapela and the Cave of Mary. However, in Kampung Bena there are also public facilities in the shape resembling the form of the Bena community traditional house which consists of the police station, Public toilets and reservoir, homestay, resident toilets, pig pens and springs. However, in general, traditional houses in the Kampung Bena have the same form of typology that distinguishes them only from the miniatures on the roof ridge.

\section{Refference}

1 Mithen. Tipologi Arsitektur Tradisional Mamasa, Sulawesi Barat. Universitas Negeri Makasar

2 Iskandar M.S.B. 2004. Tradisionalitas dan Modernitas Tipologi Arsitektur Masjid. Dimensi Teknik Arsitektur. Universitas Kristen Petra

3 https:/ /id.scribd.com/doc/108832718/Pengerti an-Tipologi

4 Defenisi Tipologi dan Morfologi Bangunanan dalam arsitektur. Sesila Vania. 
LOCAL WISDOM, Vol. 11 No. 2 July 2019

Local Wisdom Scientific Online Journal

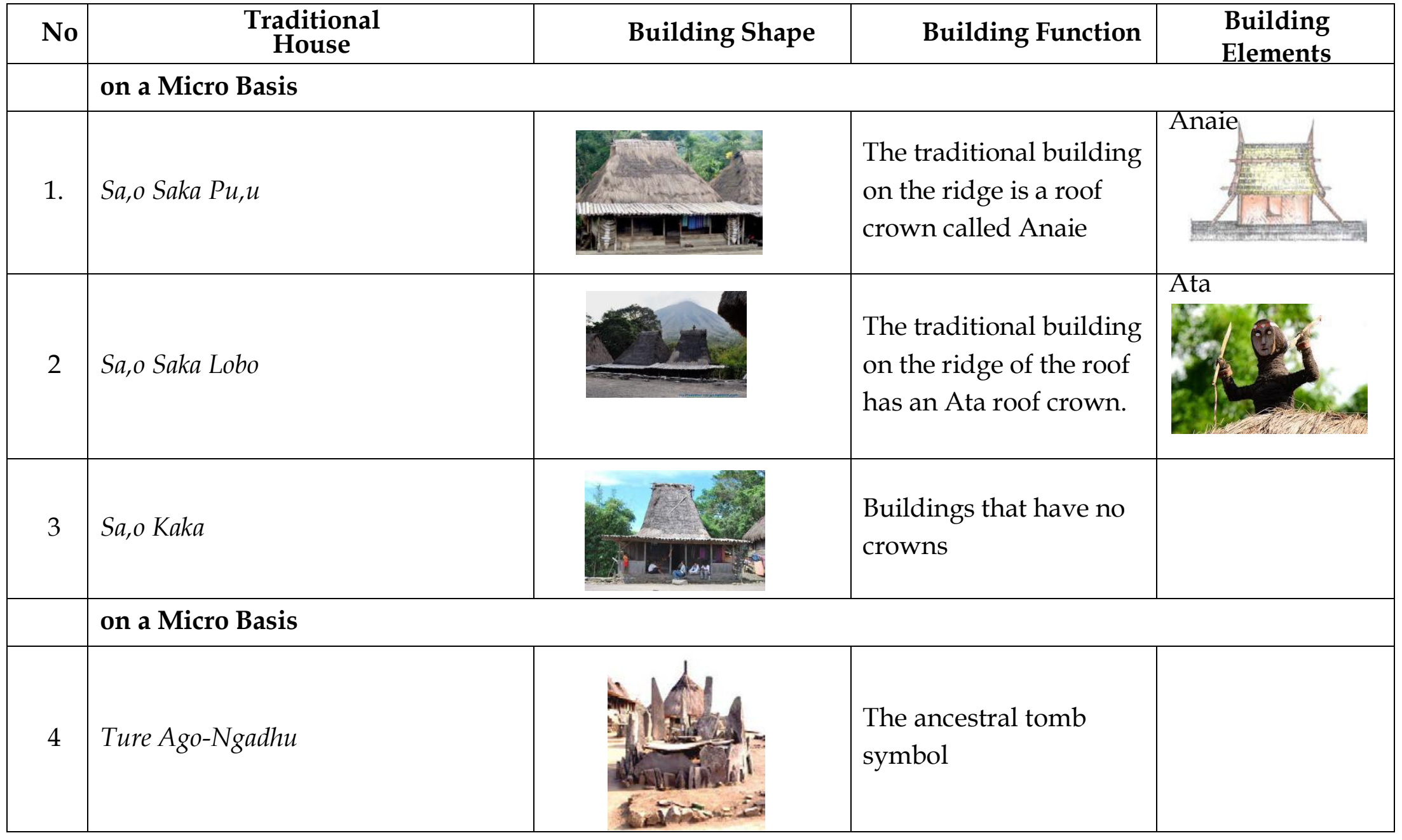


Typology of Bena Traditional Architecture, Flores

Zulkifli H. Achmad

\begin{tabular}{|c|l|l|l|l|l|}
\hline 5. & Peo & Ngadhu & $\begin{array}{l}\text { As a place to bind } \\
\text { sacrificial animal during } \\
\text { traditional ritual } \\
\text { ceremonies. }\end{array}$ & \\
\hline 7 & Bagha & $\begin{array}{l}\text { The victim's buffalo } \\
\text { rope strap and } \\
\text { symbolizes the strength } \\
\text { of men }\end{array}$ & \\
\hline & $\begin{array}{l}\text { of } \\
\text { The building without } \\
\text { any difference in front } \\
\text { of it, which always } \\
\text { opens its doors and } \\
\text { becomes the home of } \\
\text { the spirits of the } \\
\text { ancestors. }\end{array}$ \\
\hline
\end{tabular}


LOCAL WISDOM, Vol. 11 No. 2 July 2019

Local Wisdom Scientific Online Journal

\begin{tabular}{|c|c|c|c|}
\hline 8 & Ture & $\theta$ & $\begin{array}{l}\text { The arrangement of } \\
\text { stones that surround the } \\
\text { location and become a } \\
\text { barrier between places }\end{array}$ \\
\hline 9 & Kapela & & $\begin{array}{l}\text { The building used as a } \\
\text { place of worship for } \\
\text { Catholics in the } \\
\text { Kampung Bena, where all } \\
\text { Bena people are } \\
\text { Catholic }\end{array}$ \\
\hline 10 & Gua Maria & ase & $\begin{array}{l}\text { The place of the statue } \\
\text { of Mother Mary made } \\
\text { on Bowoza hill by } \\
\text { Catholic youth under } \\
\text { the care of pator Lukas } \\
\text { (1970-qn) as a means for } \\
\text { Bena residents who } \\
\text { wish to devote }\end{array}$ \\
\hline
\end{tabular}




\section{Typology of Bena Traditional Architecture, Flores}

Zulkifli H. Achmad

\section{Area/Environment Development in Kampung Bena}

The development of Kampung Bena and other vernacular villages in the Ngada cultural area as tourism destinations have made Kampung Bena open to receiving tourist visitors. Since 1990, Ngada culture has entered the list of world heritage and has become a concern of the world community. The noble products of Ngada culture, such as woven fabrics, graphic arts, music, dance, including the vernacular architecture of Bena, need to be preserved in their artefacts and developed their cultural arts knowledge to advance the knowledge and welfare of present and future generations.

The development of the tourism sector in general places more emphasis on integrated tourism promotion efforts with the activities of national and regional tourism packages. In fact, recently the uniqueness of the panorama of Kampung Bena has been utilized by aviation services and tourist accommodation in neighbouring countries to promote its activities. So that the benefits aspect of tourism is felt more by outsiders than enjoyed by clan members living in Kampung Bena. Therefore, the network management of tourism must be accompanied by an increase in the role of the clan community, the Kampung Bena indigenous people, and the Ngada cultural community, to help determine the direction of the tourism sector development policy. Thus, the local content on the vision and mission of the activity is more in line with the activities of traditional settlements that must remain. The presence of tourists must be designed in such a way that the clans can continue to hold customary rituals properly. Likewise, the activities of traditional institutions, religious activities, and administrative units of the Citizens and Tiworiwu Villages must also be managed smoothly without being disturbed by tourism activities. Thus, the design of tourism activities is the responsibility of the residents of the village of Bena itself, and the Tourism Office in the Regional Government of Ngada Regency is a facilitator and motivator in these activities. 
The development of other sectors that support tourism visits has carried out in the traditional village of Bena. Construction of tourism infrastructure and facilities, among others: roads, neighbourhood roads, public toilets, clean water channels, telecommunication lines, police posts, homestays, etc. The government does it without involving many villagers in Bena, or communities in around the traditional settlement of Bena. Communities (only) are invited to consult as far as their support is needed to realize development programs, such as when building highways, drainage channels and public toilets. The community has never been involved since the beginning regarding the preparation of regional tourism programs so that the community in Kampung Bena is positioned as an object of tourist visits only. With national, regional and international tourism networking systems, the tour packages to Kampung Bena and other villages in Ngada, or places of interest in Flores, should be aligned with the system of distribution of benefits and the benefits. The claim that Bena for all does not mean that Bena is only needed as an object of destination, but not for the benefit of the community. So, as in understanding the word "bena" which means "increasing," then tourism management and development of the village of Bena in the future must give birth to a more prosperous indigenous community, able to increase the dignity and inheritance of its ancestor. 